\title{
Ethnoecology of natural environment in trans-himalayan region of west Nepal
}

\author{
M. B. Rokaya ${ }^{1}$, M. R. Shrestha ${ }^{1}$ and S. K. Ghimire ${ }^{2}$
}

The present study was conducted during a period of two years from 2001 to 2003 in trans-Himalayan region from Mustang to Dolpa region of west Nepal. The indigenous people were found to be rich in ethnoecological knowledge regarding environment and plant resources. The locals catagorised six types of ecological land patterns such as Nakri (forest land), Penhri or pangri or Thakri or dakri (land pattern), Sim (marshy place or wetland), Lung (agricultural land) and Khangri (Snowy land). The people also had the knowledge of plants in population level and species level and had their own way of classifying them on the basis of different criteria like presence or absence of flower, habit, habitat, morphology, etc.

Key Words: Ethnobotany; Indigenous knowledge; Folk nomenclature; Folk classification

$\mathbf{T}$ he indigenous people in different parts of Nepal Himalayas have been utilizing physical and natural environment in various ways since the time immemorial. The indigenous people in a particular geographical area have perceived environmental component at the landscapes level, species level and population level in different ways and categorised and delimited these components according to their specific local systems and terms.

Ethnoecology, the applied field of ethnobotany, is a study of local knowledge with respect to surrounding environmental components. A broad definition given by Toledo (1987) and modified by Patton (1993) defined ethnoecology as 'the study of all the knowledge, strategies, attitudes and skills that permit rural cultures to produce and reproduce the material conditions of their social existence through an appropriate management of natural resources.' Today in different parts of the world, participatory ethnoecological researches, have been directed towards the conservation and management of biological diversity. (Aumeeruddy, 1998 cited in Ghimire et al., 2001). The present paper highlights ethnoecological knowledge of indigenous people living in trans-Himalayan region regarding the nomenclature of physical and biological environment.

\section{Materials and metohds}

Study site

The study area lies in between $28^{\circ} 45^{\prime}-29^{\circ} 45^{\prime} \mathrm{N}$ latitude to $82^{\circ} 20^{\prime}-83^{\circ} 45^{\prime} \mathrm{E}$ longitude covering part of upper
Mustang and upper Dolpa in trans-Himalayan zone. The site is represented by its richness in alpine and arid flora with its phytogeographic uniqueness. Areas are almost treeless and virgin, pristine with arid transHimalayan ecosystem (Snellgrove, 1961; Ghimire et al., 2001; Rokaya, 2002; Shrestha, 2004), located at the rain-shadow zone beyond the high mountain ridges formed by Mt. Dhaulagiri, Annapurna and Kanjiroba massif, which forms barrier to most of the monsoon precipitation that comes from southeast (Hagen 1960). The climate is similar to Tibetan Plateau with higher solar radiation and extremely low precipitation, and it ranges from cool and humid to arctic and cold desert types (Carpenter and Klein, 1995; Sherpa, 1992; Yosida, 2002). Annual rainfall drops $250-500 \mathrm{~mm}$ along the Tibetan borderland in western Nepal because of rain shadow and distance from the Bay of Bengal (Manandhar, 2002; Rokaya, 2002; Shrestha, 2004).The population is of Tibetan origin hence follow Tibetan culture, social, and religious systems (McVeigh, 1994; Bista, 2000; Rokaya, 2002) and speak Tibetan language. Religions include Bon and Buddhism. Bon is the ancient religion prevailed in Tibet prior to Buddhism (cited in Ghimire et al., 1999).

\section{Data collection}

The fieldwork was conducted in the study area at two different periods during October 2001-July 2003. Participatory methods such as Rapid Rural Appraisal (RRA), Participatory Rural Appraisal (PRA),

1. G.P.O.Box no 15142, KPC 319, Kathmandu, Nepal

2. Lecturer, Central Department of Botany, T. U., Kathmandu, Nepal

Corresponding author's : rokayamaan@gmail.com/rokayamaan@hotmail.com 
participant observation, focus group discussion and key informant interviews (Martin, 1995; Rastogi et al., 1998; Cunningham, 2001) were employed. The participatory assessment was done in parallel way by conducting through a group discussion with the people from different localities asking different questions related to identification of plants, their use, distribution, habitat, vernacular name or local name, to folk taxonomy and nomenclature.

\section{Results and discussion}

The people of the study area were found to be exceptionally rich in their indigenous knowledge regarding the environmental factors, resources, and conservation and management aspects. They have their own terms for the level of categorization of land resources and for entire world of plants, which are cited below:

Indigenous knowledge at landscape level: There are various types of ecological zones differentiated by local people in different kinds of geographical settings. The major six land use categories based on local perception are as follows:

a. Nakri (forest land): It is differentiated into singhna (forest), na (shrubby land), singdong (forest with only large trees).

b. Penhri or pangri: It is differentiated into four categories - pang (grassland), degha (big flat land), thang (a big field), ya (high alpine grass land).

c. Thakri or dakri: It has four different subcategories as: $d z a$ or $d a k$ (rocky land), ghyapa (land full of gravel and coarse stones), yama (a place with slippery stones) and chyanh (highly rocky slope).

d. Sim (marshy place or wet land): It is differentiated into different sub-categories as: tsangdam (a river bank), lungba (a river between two hills), nah jok. (marshy land) and ya tsangdam (moist place of high mountain or Himal).

e. Lung (agricultural land): It is differentiated into two sub-categories - zhing or zingga (crop cultivated land) and livijing (homestead land).

f. Khangri (Snowy land): It is also differentiated into two sub-categories which are $d z a$ (permanent

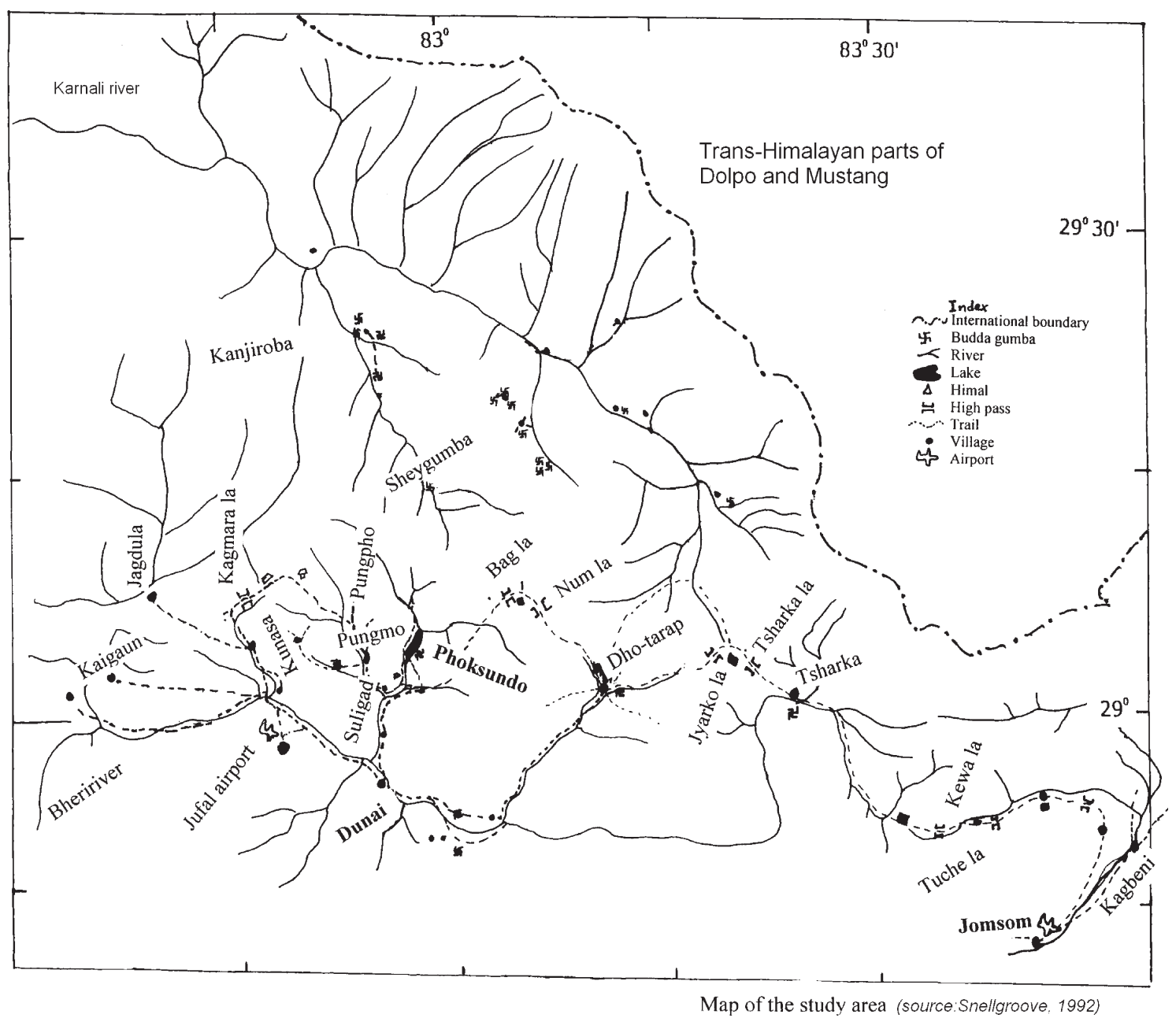

Map: The Map showing routes taken by researchers in Trans-Himalayan Parts of Dolpo and Mustang 
snow melting zone) and ghya (a place above the snow line).

Different forests and shrub lands are named according to different landmarks erected by the people for religious purposes. For example, the two Juniper forest patches in Kalang named as Lang-rok forest and Gygao-chu forest, the three patches of shrub lands and nine pastures in Dho-Tarap area are named in accordance to the prominent landmarks, such as gombas (monastery), laptsai, mani or madong and chortens (stupas), etc. The pastures that are highly important resources for the survival of local livestock and other biotic agents are of two major types: summer pastures and winter pastures. Among the eight pastures present in Dho-Tarap valley of Dolpo, the one named as Lang pasture is the only winter pasture. The summer pastures are Shulak Pasture, Mirobo pasture, Sorbo pasture, Pen pasture, Shorbu pasture, Traye pasture, Numala pasture that were named on the basis of landmarks.

Indigenous knowledge at plant population level: On the basis of plant population assessment, the local people defined population size as thick (thukpo), thin (tapo) and moderate (dingba) with respect to plant distribution patterns. For the specific distribution pattern, the terms used before the thin, thick and moderate patterns are everywhere (sane yongjok), somewhere (sane dingba), and few places (sane nyungnyung).
Indigenous knowledge at species level: The people of the study area are knowledgeable regarding biological component such as plants. Their folk classification was on the based on various criteria such as presence or absence of flowers, habit, habitat etc. These are described below:

a) On the basis of flowers: The whole plant kingdom or the plant world is called as ngo-men-ri. The flower bearing plants are named as metog bharyap (angiosperms) and non-flowering plants are called as metog menpa (mostly includes cryptogams). The higher plants are called as trees (sing dong), shrubs (singten), herbs (ngodum) and thrilsing (climbers).

b) On the basis of habitat: The whole plant kingdom (ngho-men-ri) has been divided into different categories on the basis of the habitat of the plants: tshu ruk (aquatic), thangla haepa (terrestrial plants), sing bal (epiphytic plants), dhotak (plants growing on the stones).

c) On the basis of the habit or structure: This classification system of plants is more comprehensive and gives the detail account of the whole plant kingdom, ngo-men-ri (Fig 1). It is differentiated into two sub categories as ngo dhum (herbaceous plants) and sing (woody plants). The ngo dhum is further differentiated into tsa (grasses) and ngodhum (herbs). The herbs on the basis of size of fruits, roots, and flowers are differentiated into various categories such as debu tshae (plants

The categories of plants defined by local people and amchis of trans-Himalayan zone of west Nepal

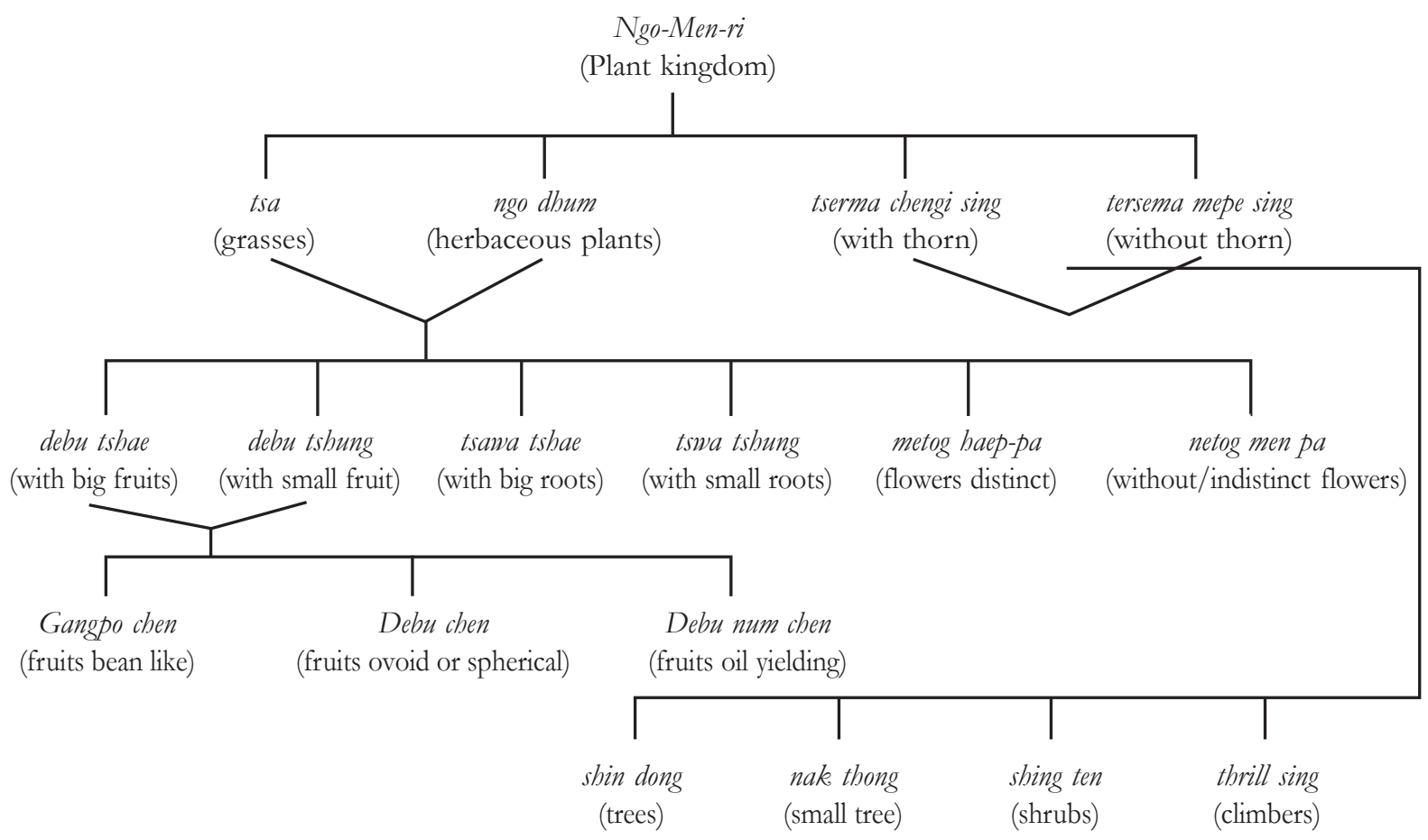


with big fruits), debu tshung (plants with small fruits), tsawa tshae (plants with big roots), tsawa tshung (plants with small roots), metog haep-pa (plants with distinct flowers), and metog menpa (plants with small or indistinct flowers). On the basis of the structure and the property of fruits the plants are further differentiated into gang po chen (plants with bean like fruits), debu chen (plants with ovoid or spherical fruits), debu num chen (plants with oil yielding fruits). The woody plants (sing) are differentiated into tserma chengi sing (thorn bearing plants) and tserma mepe sing (plants without thorns). They are further differentiated as sing dong (trees), na jok (small trees), singten (shrubs) and thrilsing (climbers).

The folk system of nomenclature: The folk system of nomenclature of plants is based on the particular characteristics such as use, life forms, habitat, morphology, properties of plants etc.

a) Nomenclature based on plant habit: Many plant names refer to plant habit or life form categories such as trees (sing), grass or grass like (tsa), small plants (tsungba), thorny (tser or tserma), etc. For example thesing (Pinus wallichiana), tsa awa (Carex sp.), tsa (Juncus sp.), jiptsi tshungba (Lamium tuberosum), thang na sing (Abies spectabilis), chang tser (Morina polyphylla).

b) Nomenclature based on habitat: Plants are also named on the basis of the specific habitat as pang (meadows), drak (rocky mountain cliff), nak (forest), tsh $u$ (water), etc. For example, the plant name tshu babal (Spirogyra sp.) is given as the plant grows in the water $(t s h u)$ and looks like wool (babal). The name tshu tsa is given for the aquatic grass. The term pang stands for grassland and thong for straight in habit, thus the plant growing straight in grass land is called as pang a thogn (= pang a tung), for example Androsace strigillosa. Likewise the name thsuma tsi or chumatsi (Oxyria digyna) has been derived for the plant being aquatic (tshu) and growing in mass or in groups of many $(t s i)$. The term drak refers to the layer or the accumulated rot. The term chudrak refers to a layer of small plants accumulated in the water; dhodrak for the layer of the plants on the rock and appearing as if it is a layer of rot; and sing drak refers to a rot like plants on the trees. The plant name kangla metog (Saussurea sp.) is derived from different words as ' $k a n g$ ' meaning snowy place, ' $l a$ ' meaning sloppy land and 'metog' meaning flower. Thus kang la metog means a flower in the sloppy and the snowy place. Likewise, the name pang ram (Bistorta sp.) has been derived from two words 'pang' meaning grassland and 'rabae' meaning looking in dense population. So, pang ram means the plant appearing to be dense in the grassland area.

c) Nomenclature based on plant morphology: The system is based on the structure of plant in reference to colour and the special appearances. For example, 'japo' means cock and ' $t s i$ tsi' means the comb and the plant with the flower resembling to the cock's comb is named as japo tsi tsi (Coleus barbatus). The different species of Pedicularis are named with the prefix 'lugru' meaning sheep's horn as the flowers has the coiled beak similar to horn of the sheep. The name kyiche karpo (Gentiana robusta) has been derived as Kyi- dog, che - tongue and karpo - white as the leaves of the plant are similar to the tongue of dog with the white flowers. Sang dril serpo (Primula sikekimensis) has been derived from different words as sang - bell, drilto ring and serpo - yellow for the plant with the yellow flower in the shape of ringing bell. The suffixes karpo (white), serpo (yellow), ngon po (blue or violet), marbo (red) are used with reference to the colour of the flower. For example, balu marbo (Rhododendron lepidotum - red flowered Rhododendron), balu ngon po (Rhododendron nivile - dark red flowered Rhododendron), lugru serpo (Pedicularis klozschii - yellow flowered Pedicularis), etc.

d) Nomenclature based on plant use: The use of the plant is also a basis of naming plant. Terms representing specific utilities of plants like $m-n$ (medicine), dbuk tsa (poison), poe (scent or incence), etc. are given as suffixes or prefixes to name specific plants. For example, sila poe (Jurinea dolomiaea) has derived from two words sila (meaning the avoidance of the bad smell) and poe (meaning scent or incense). Thus the plant name sila poe stands for the scent used to avoid the bad smell. M-ntsa (medicinal grass) and dhuk tsa (poisonous grass) are also named according to the use of the plants.

e) Nomenclature based on plant property: The plants are also named based on their property. For example bitter is locally called tik (= tig) or $k b a$. The plants with such taste are tikta (Swertia sp.), Bashakha (Lagotis kunawurensis), gyatig (Androsace strigillosa, Swertia ciliata), zintik (Ajuga lupulina). Plants with acrid taste are known as tsa, for example chetsa (Ranuculus sp.), and chumtsa (Rheum sp.), etc. The name pang poe (Nardostachys grandiflora) is given for the scented plant (poe) in the grassland (pang). 
Indigenous knowledge on the biology and life cycle stages of plants: The local people were found knowledgeable in biology and life cycles of plants. The identification of plant during its life cycle is very important because its potency depends on the different stages of the life cycle. The stages in the cycle based on the local perception are dheubu (seeds), khabui (seedling), dhurtsi or lomakae thuk (juvenile stage), thong bo kae thuk (mature plant), metog kae thuk (flowering stage), dubu kae thuk (fruiting stage). The plants that propagate through roots are called chab nae kae $d u$ and those through seeds are thap tae kae $d u$.

The people generally identify plants on the basis of taste of different plant parts, types of the root structures and different life cycle stages. The most important account is taken that of structure, fragrance, colour and the taste of the flowers and the seeds. The people are well aware of the conductance and the storage of the sap in the plants, and use the different parts of the plants according to the perception of nutrients level in different plant parts. Thus, they use the various parts of the plants in different time of the year and at the various stages of the life cycle. For example people use seeds during December to January, shoots during February to April, flowers during May to August, and roots during September to November.

The land categorization system is comparable to the scientific classification of the ecosystems as terrestrial, aquatic and artificial ecosystems. Further these major categories are sub-categorized into smaller units. The classification is natural and is on the basis of the habitat of the plants that is similar to scientific classification of the ecosystems. The naming of the forest and the pastures are on the basis the presence of prominent landmarks and is similar to the other parts of Nepal (Ghimire et al. 2001; Lama et al., 2001).

Folk nomenclature and classification system in some extent is comparable with the scientific classification system. However, the local classification of the plants is not so explicit so that there is lack of detail categorization of the plant up to specific level. Locally the plants have been classified as metog bharyap (flowering plants) and metog menpa (non-flowering plants) and it is similar to the phenerogams (flowering plants) and cryptogams (non-flowering plants) of scientific classification. The life form and the intermediate levels between the folk ranks and the scientific taxa are not sharp. The life form categories such as tsa (grass) and ngodum (herbs) have some correspondence to monocotyledons (or scientific family - Graminae and Cyperaceae) and the herbaceous dicotyledons. The monocotyledons other than grass-like are grouped in ngodum (herbs). On the other hand tserma chengi sing (with thorns) and tserma mepe sing (with out thorns) or the plants with distinct flowers and the plants with indistinct flowers corresponds to angiosperms or gymnosperms. But the demarcation of this category is not distinct and prominent. In a systematic classification the family is a category comprising one of more genera or tribes of common phylogenetic origin and the plants have a common ancestor that have evolved into various species along and evolutionary process, but this sorts of criteria is not available in the local system of classification (Ghimire et al. 2001). However, the system of classification is so large that the plants could be identified up to generic level with the systematic identification.

The folk nomenclature of plants is similar to scientific nomenclature. In the folk nomenclature given name of the plant is based on different morphological and physical characteristics. The term representing these characteristics is given in the form or prefix or suffix. At the generic level and the varietal level the plants are named on the basis of different attributes as habit, habitat, morphology of the flowers, use, property of the plants, plant size, etc. The system of nomenclature is also in some places binomial. However, according to Ghimire et al. (2001) the correspondence between folk nomenclature and the scientific nomenclature exist in a large scale.

Regarding the life cycle in indigenous concept the various steps are well differentiated right from seed (dhaebu) to the fruiting plant (dhaebu kaethuk). Although the ethnoecological knowledge is rich, the identification of the plants is still not so scientific as the account of fragrance or the parts of the plants are taken into consideration. The level of perception on the potency of the plant based on nutrient concentration looks scientific because the local people use the plant parts according to the seasonal calendar.

\section{Conclusion}

The present study focussed on ethnoecological knowledge of indigenous people of trans-himalayan region of west Nepal showed good level of knowledge regarding natural environment at different levels. Indigenous people have differentiated the ecological zones on the basis of land use categories. It was further found that folk nomenclature system and folk classification of the plants were based on the different aspects such as presence or absence of 
flowers, habitat, habit and morphological structure, use and property. In this modern world, it is important to document indigenous knowledge regarding natural resources in order to make effective strategies to conserve natural resources for the future generation.

\section{Acknowledgements}

We are grateful to a number of local people, amchis, Phurba Lama, Norbu Lama, Karwang Lama, amchi Karma Lama and amchi Namgyal Lama who shared their indigenous knowledge of utilizing plants as medicines. We are also indebt to Yeshi C. Lama, WWF Nepal Program, Amchi Gyatso Bista, Mustang, Dhana P. Shahi, N. Kurrmbang and PPI/WWF Nepal for their enormous help in the field. We thank WWF Nepal Program for providing financial support to carry out the present research.

\section{References}

Aumeeruddy, Y. 1998. Ethonobotany, the culture and social division-linkages with conservation and development. In: Shretha, K.K., P. K. Jha, Pei Shengji, A. Rastogi, S. Rajbhandri and M. Joshi (eds.), Ethnobotany for conservation and community development. Proceedings of National Training Workshop in Nepal, Ethnobotanical Society of Nepal (ESON), p. 5-9.

Bista, D. R. 2000. People of Nepal. $7^{\text {th }}$ edition, Ratna Pustak Bhandar, Kathmandu, Nepal.

Carpenter, C. and J. Klein. 1995. Plant species diversity in relation to grazing pressure in three alpine pastures, Shey Phoksundo National Park, Nepal. WWF Nepal Program Report Series No. 20. WWWF Nepal Program, Kathmandu, Nepal.

Cunningham, A.B. 2001. Applied ethnobotany: people, wild plant use and conservation. A People and Plants Conservation Manual, Earthscan, London, 300p.

Ghimire, S. K., D.B. Parajuli, T.N. Gurung and Y. C. Lama. 1999. Conservation of the Plant Resources, Community Development and Training in Applied Ethnobotany at Shey Phoksundo National Park and its Buffer-zone, Dolpa. WWF Nepal Program Report Series No. 38, WWF Nepal Program, Kathmandu, Nepal.

Ghimire, S. K., Y. C. Lama, G. R. Tripathi, S. Schmit and Y. Aumeeruddy Thomas. 2001. Conservation of the Plant Resources, Community Development and Training in Applied Ethnobotany at Shey Phoksundo National Park and its Buffer-zone, Dolpa. Fourth Year. WWF Nepal Program Report Series No. 41, WWF Nepal Program, Kathmandu, Nepal.
Hagen, T. 1960. A brief survey of geology of Nepal. United Nations commissioner for technical consistence, Department of Economic and Social affairs, Prepared for Government of Nepal.

Lama Y. C., Ghimire, S.K. and Y. Aumeeruddy Thomas. in collaboration with the amchis of Dolpo. 2001. Medicinal plants of Dolpo amchis' knowledge and conservarvation. People and Plants Initiatives, WWF Nepal Program, Kathmandu, Nepal.

Manandhar, N. P. 2002. Plants and People of Nepal. Timber press, USA. p 18-27.

Martin, G. J. 1995. Ethnobotany: A people and plants consevation manual. Chapman and Hall.

McVeigh, C. 1994. Indigenous resource management systems among Tibetan-speaking herders in western Nepal. Report submitted to United States Agency for International Development (USAID), Kathmandu.

Patton, D. 1993. Ethnoecology: the challenge of cooperatiom. In: Etbnoecologica Vol I, No. 2.

Rastogi, A., Godbole, A. and Shengji, P. 1998. Applied ethnobotany in natural resource management- traditional home gardens. International Centre for Integrated Mountain Development (ICIMOD), Kathmandu, Nepal.

Rokaya, M. B. 2002. Ethnoecology of Medicinal Plants in Dho-Tarap Area in Buffer Zone of Shey-Phoksundo National Park, Dolpa, Nepal. Unpubl. M. Sc. Dissertation, Central Department of Botany, Tribhuvan University, Nepal.

Sherpa, N. W. 1992. Operational plan: SheyPhoksundo National park, Nepal. WWF Nepal Program, Kathmandu, Nepal.

Shrestha, M. R. 2004. Trans-Himalayan Dicot flora of Northwest Nepal: Dolpo and Its surroundings. Unpubl. M. Sc. Dissertation, Central Department of Botany, Tribhuvan University, Nepal.

Snellgrove, D. 1961. Himalayan pilgrimage. Oxford, 304 p.

Toledo, V. M. 1987. Ethnoecology, peasant economy, and rural production in Mexico. Unpublished text of a speech presented at the university of California, Berkeley.

Yoshida, T. 2002. Additive strategies of alpine plants in Nepal. In: Noshiro, S. and K.R. Rajbhandary (eds.) Himalayan Botany in the Twentieth and Twentyfirst Centuries. The Society of Himalayan Botany, University museum, university of Tokyo, Tokyo, Japan. p. 105-111 